\title{
Ethnologies
}

\section{Tracking Doctor Lonecloud: Showman to Legend Keeper. By Ruth Holmes Whitehead. (Fredericton, NB: Goose Lane Editions \& Nova Scotia Museum, 2002. Pp. 183, ISBN 0864923562)}

\section{Ann Marie Powers}

Volume 30, numéro 2, 2008

Hommage à Peter Narváez

In Honour of Peter Narváez

URI : https://id.erudit.org/iderudit/019957ar

DOI : https://doi.org/10.7202/019957ar

Aller au sommaire du numéro

Éditeur(s)

Association Canadienne d'Ethnologie et de Folklore

ISSN

1481-5974 (imprimé)

1708-0401 (numérique)

Découvrir la revue

Citer ce compte rendu

Powers, A. M. (2008). Compte rendu de [Tracking Doctor Lonecloud: Showman to Legend Keeper. By Ruth Holmes Whitehead. (Fredericton, NB: Goose Lane Editions \& Nova Scotia Museum, 2002. Pp. 183, ISBN 0864923562)]. Ethnologies, 30(2), 282-283. https://doi.org/10.7202/019957ar d'utilisation que vous pouvez consulter en ligne.

https://apropos.erudit.org/fr/usagers/politique-dutilisation/ 
Titon, Jeff Todd. 1985. "Knowing Fieldwork." In G regory F. Barz and Timothy J. Cooley eds., Shadows in the Field: $\mathrm{N}$ ew Perspectives for Fieldwork in Ethnomusicology: 87-100. N ew York: Oxford U niversity Press.

W razen, Louise. 1988. "The Góralski of the Polish Highlanders: Old World Musical Traditions from a New World Perspective." PhD dissertation, U niversity of Toronto.

Tracking Doctor Lonecloud: Showman to Legend Keeper. By Ruth Holmes Whitehead. (Fredericton, NB: Goose Lane Editions \& Nova Scotia Museum, 2002. Pp. 183, ISBN 0864923562)

This delightful book includes the ethnography, folklore and cultural history of the nineteenth and early twentieth century $\mathrm{Mi}$ 'kmaq, as narrated by Jerry Lonecloud (a.k.a. Germain Bartlett A lexis) and told to Clara Dennis and Harry Piers. Ruth W hitehead has patiently and painstakingly sifted through Lonecloud's memoirs, stories and legends to present us with an insider's view of what it was like to grow up as a M i'kmaq in a white man's world. We learn how Lonecloud was taught the secrets of the medicine by his grandparents; how he received his name (from the white man who hired him to be part of his W ild West Medicine show because he wanted to sell Indian authenticity); and how he learned to adapt in the white man's world through appropriation (for example, in his legends and stories about medicine he often used the white man's terms, such as "tom-tom" or "squaw"). A s he said of himself, Jerry Lonecloud was a showman.

Throughout the book, we are enchanted by Lonecloud's reflections, insights, and humour. For example, in his discussion of missionaries, he explains how one priest in Nova Scotia would not leave the village until all of the people agreed to be christened and how this created change among them. Likewise, he talks about the M i'kmaq language, indicating that there were no curse words in their language until the white man came. of his responsibilities as a medicine man, he says that the chief medicine man was the keeper of the medicine and the storyteller. He could also marry people and often would be the village disciplinarian. Reading between the lines, we realize that the medicine 
man had a good deal of power among his people. In Part II we are treated to some of Lonecloud's medicinal recipes, and in Part III to some of the legends that were part of $\mathrm{M}$ i'kmaq tradition.

Lonecloud was a master showman and an important leader for his people. He moved back and forth between two worlds and used the knowledge he garnered to try to effect positive change. For example, his memoirs contain several letters he wrote on behalf of the M i'kmaq seeking property rights to their land in parts of N ova Scotia and N ew Brunswick. H is wisdom is apparent in his discourse on disease. Jerry Lonecloud knew who he was writing for and knew just what to say. Depending on his audience, the discourse changed. O $\mathrm{n}$ disease he writes: "W hen the Lord put disease on earth, he put medicine, and he put man to locate medicine. It is handed down like traditions... . I have cured fits, asthma. I treats miners what get choked with dust" (87). But, later on he also writes of disease: "Bad spirit gives you disease.... Indians make medicine and go through a ceremony with the medicine to drive out the evil spirit before they take it, so the evil spirit can't leave any sting upon the body" (80).

Part III of the book contains some of the stories and legends that Lonecloud learned during his lifetime. Interestingly, he entwines his experiences into traditional tales, so the listener can identify with the stories being told - white man or native, the stories carry their message.

This book adds to our repertoire of knowledge about the M i'kmaq, from the medicines they used, to their language, as well as their attitudes towards gender. Indeed, the story of the first canoe is about the woman who dreamt of one and then built it. I recommend this book to anyone interested in learning more about Jerry Lonecloud or about the culture of the M i'kmaq during the turn of the last century, including a number of interesting pictures (Lonecloud and his family), diagrams (how to build a wigwam), and countless stories.

A nn M arie Powers A cadia U niversity Wolfville, N ova Scotia 